\title{
СОВЕТСКИЙ СОЮЗ И САУДОВСКАЯ АРАВИЯ МЕЖДУ МИРОВЫМИ ВОЙНАМИ
}

Наумкин В.В. Несостоявшееся партнёрство. Советская дипломатия в Саудовской Аравии между мировыми войнами. М.: Институт востоковедения РАН; Аспект Пресс, 2О18. 456 с. Naumkin V. Failed Partnership. Soviet Diplomacy in Saudi Arabia Between World Wars. Moscow: Institute of Oriental Studies RAS; Aspect Press, 2018. 456 p.

Монография Виталия Вячеславовича Наумкина, действительного члена Российской академии наук, научного руководителя Института востоковедения РАН, лауреата Государственной премии по науке за 2018, обладает многими достоинствами. Особо отмечу многоплановость и многоаспектность анализа; использование материалов из Архива внешней политики Российской Федерации и архива британского Форин-офиса; уважительный, хотя подчас и критический подход к работам своих коллег; богатство иллюстративного материала; филигранную тщательность примечаний.

В короткой рецензии попробую остановиться на некоторых из отмеченных особенностей книги. Речь пойдёт прежде всего о многогранности исследования, наличии в нём нескольких проблемно-тематических пластов, сложно переплетённых и органично взаимосвязанных. Первый это сама история советско-саудовских отношений в 1920-х-1930-х годах, тяжёлая, подчас героическая работа советских дипломатов, трудившихся в изнуряющей жаре под прессингом как местной обстановки, так и требований из Москвы. Второй пласт составляет анализ ситуации на Ближнем Востоке в последние годы Первой мировой войны и после её окончания, социально-политического строя в
Аравии, борьбы за королевство Хиджаз, его завоевания правителем Неджда Абдель Азизом ибн Саудом, дипломатических контактов и внешнеполитических связей объединённого королевства. Третий - связан с разбором внешней политики СССР на саудовском и, шире, ближневосточном направлении, её эволюции, противоречий между общегосударственными задачами и приоритетами отдельных ведомств, вовлечённых в её реализацию.

Основываясь на богатейшем фактическом материале, автор в рамках рассматриваемого периода выявляет три этапа эволюции дипломатических отношений СССР и королевства Хиджаз (с 1932 г. Саудовского королевства). В ходе начального периода с 1923-1924 до 1927-1928 гг. отношения развивались по нарастающей. Далее, до 1932-1933 годов, они носили неровный характер. Наконец, на завершающем этапе двусторонние связи угасали и фактически сошли на нет в апреле 1938 года, когда дипломатические отношения фактически были прекращены в одностороннем порядке саудовским королём (хотя формально они разорваны не были) (С. 446).

С советской стороны главное действующее лицо начального этапа - первый «дипломатический агент и генеральный консул» в Джидде, уроженец Башкирии, революционер, участник Гражданской войны, 
по её окончании перешедший на службу в Народный комиссариат по иностранным делам (НКИД) К.А. Хакимов. Он заложил основы отношений с Хиджазом, который в первое время после его приезда находился под властью королей из хашимитского рода шерифов Мекки. К.А. Хакимов успешно наладил отношения со сменившим хашимитов Ибн Саудом, что было деликатным и нелёгким делом. СССР первым признал Ибн Сауда главой нового государства (С. 142-143).

К 1927 году, когда настойчивые просьбы К.А. Хакимова о замене из-за ухудшения здоровья были удовлетворены, контакты с королевством уже опирались на прочный фундамент. Со вторым представителем СССР, казахом Н.Т. Тюрякуловым, связаны следующие этапы эволюции двусторонних связей. Ему, как и предшественнику, а также временно исполнявшему обязанности генконсула Ю. Туйметову удалось наладить отношения с королём, правительством, а также с дипломатическими представителями других стран. Вплоть до начала 1930-х годов взаимодействие между двумя государствами развивалось успешно. В 1930 г. был повышен статус советского представительства - дипломатический агент и генконсул стал полномочным представителем и чрезвычайным посланником (C. 343). Однако иностранные конкуренты и местные недоброжелатели препятствовали установлению нормальных торговых связей между СССР и королевством, долгое время сохранялся дискриминационный режим на поставки советских товаров.

Особенности становления и эволюции Саудовского королевства (второй пласт исследования) охарактеризованы в книге сжато и ёмко. Осветив традиционную социальную структуру в аравийских обществах, осложнявшуюся различиями в жизненном укладе членов племён и жителей городов, отметив частые войны и набеги, межплеменную и внутриплеменную рознь, господство «патронажно-клиентельной» системы, В.В. Наумкин касается истории дома светских правителей Саудидов, установивших в XVIII в. взаимовыгодный союз с «популярным богословом и проповедником» Абдель Ваххабом, создателем крайне ригористического, пуританского религиозного учения (С. 14).

После разгрома в начале XIX в. первого саудидского государства, в середине того же столетия возникло второе, а в начале XX века - третье, во главе с молодым (родился в 1880 году) Абдель Азизом. Центр его власти лежал к западу от Хиджаза, в отделённой от него горами области Неджд. В 1902 г. Абдель Азиз отобрал главный город области, Эр-Рияд, у своих соперников Рашидидов, которым оказывала покровительство Османская Турция. В союзе с ваххабитскими богословами (улемами) Абдель Азиз принялся насаждать «истинный ислам» среди арабов-бедуинов. Так возникло движение ихванов, братьев по истинному единобожию. Господство Османов в Аравии накануне Первой мировой войны носило почти формальный характер, а после её начала реальный патронаж перешёл к Британии. Последняя договором 1915 г. признала власть Ибн Сауда над Недждом и рядом присоединённых областей (ЭльХаса и др.) (С. 17-18).

К середине 1920-х годов власть хашимитов в Хиджазе держалась на волоске под ударами ихванов Ибн Сауда. Заняв Мекку и разрушив там все гробницы, кроме могилы Пророка, его воины в декабре 1925 г. заняли Джидду. Абдель Азиз был провозглашён королём Хиджаза, оставаясь султаном Неджда и присоединённых областей. B.В. Наумкин указывает на необычность возникшего государства, называя его «аравийским кентавром». Он детально прослеживает создание и совершенствование системы управления в «двусубъектном» государстве Ибн Сауда, его продуманные шаги по «подтягиванию» Неджда до уровня Хиджаза, который к тому времени уже модернизировался в административном и социальном отношении по наиболее передовым в арабском мире образцам (C. 164-166).

Самым актуальным представляется третий проблемно-тематический пласт монографии В.В. Наумкина, связанный с ос- 
мыслением внешней политики Советского Союза на Востоке, которая раскрывается через судьбы людей, его определявших и проводивших.

Ведущее место среди тех, кто проложил Советскому Союзу дорогу в Аравию, автор справедливо отводит наркому иностранных дел Г.В. Чичерину. В.В. Наумкин отмечает, что его считали «англофобом, германофилом и туркофилом, что, конечно, было сильным преувеличением» (С. 69). Тем не менее эмоции действительно играли известную роль в жёстких антианглийских позициях наркома. Приведена интересная деталь, характеризующая работу НКИД времён Г.В. Чичерина. В его структуре было всего два территориальных (позднее территориально-политических) отдела: Запада и Востока, с рядом подотделов (С. 50). На восточное направление нарком смотрел в основном через призму борьбы с главным соперником - Великобританией. В этой связи сбор информации о деятельности и планах англичан входил в задачи советских представителей в Хиджазе. Им предписывалось вести себя корректно, избегая возможных провокаций. Особенно осторожно пришлось действовать после разрыва Великобританией торговых и дипломатических отношений с СССР в мае 1927 года (С. 216).

Этот шаг, вызванный деятельностью «левых» в Коминтерне, напоминает о том, что НКИД был не единственной структурой, проводившей советскую внешнюю политику. Деятельность образованного в 1919 г. Коммунистического Интернационала была особенно энергичной на первых порах. Да и в дальнейшем советская политика строилась исходя не только из прагматических государственных интересов, но и из соображений идеологических, преследуя цель распространения революционной, коммунистической идеологии. Кризис 1927 года, как отмечается в книге, сказался на отношениях с Ибн Саудом «не так сильно», поскольку его государство квалифицировалось как «патриархально-феодальное», где нет перспектив для революционной работы.
Трудные времена мешали проведению курса НКИД. Г.В. Чичерин переживал в то время, по словам В.В. Наумкина, «серьёзный личный кризис», связанный и с ухудшением здоровья, и с глубоким разочарованием из-за укрепления личной власти Сталина, первых репрессий, безуспешности попыток профессионально выстроить работу своего ведомства. В 1930 г. последовала отставка народного комиссара, скончавшегося в 1936 г. в Москве, где, страдая от болезней, он вёл затворнический образ жизни (С. 325-327).

При новом наркоме М.М. Литвинове внимание к Саудовской Аравии в середине 1930-х годов заметно ослабло. Восток, как пишет автор, «почти совсем не интересовал» руководителя дипломатического ведомства. Сказались к тому же чистки в аппарате НКИД (С. 435-436).

Тем не менее заключённая в мае 1931 г. сделка по продаже в королевство бензина и керосина была серьёзным достижением советской дипломатии в борьбе за саудовский рынок (С. 368-369). Договор предусматривал уплату неустойки в случае нарушения его условий, и уже к 1932 г. в связи с ухудшением финансового положения королевства вопрос о «нефтяном долге» приобрёл немалое значение для двусторонних связей (С. 403-404). По причине охватившего капиталистический мир экономического кризиса Саудовское королевство остро нуждалось в деньгах и серьёзно рассчитывало на финансовую поддержку Советского Союза. Сын Абдель Азиза, эмир Фейсал, занимавший пост министра иностранных дел, во время европейского турне, летом 1932 года, побывал с визитом в СССР. Эмир был принят на самом высоком уровне, но положительного результата визит не принёс, поскольку «советское правительство не пошло на предоставление кредита королевству» (с. 391). Усилия Н.Т. Тюрякулова, продолжавшего пользоваться расположением короля и министров, разбивались о равнодушие и недовольство Москвы. В январе 1936 г. его освободили от работы, а в 1937 г. арестовали и впоследствии расстреляли. Такая же тра- 
гическая участь постигла К.А. Хакимова, Ю. Туйметова и ряд ответственных сотрудников миссии.

Закончить рассказ о советско-саудовских отношениях в 1920-х - 1930-х годах хотелось бы словами В.В. Наумкина из эпилога: «Эта книга, в которой автор поставил перед собой задачу рассказать о достижениях советской дипломатии в Аравии в период между мировыми войнами, возможно, получилась несколько грустной. Но я не хотел превратить её ни в панегирик, ни в мартиролог. То, как работали в тех краях наши отечественные дипломаты, разведчики и востоковеды, всегда вызывало у меня чувство восхищения, и я надеюсь, что его разделит со мною читатель» (С. 451-452). И ещё одна цитата: «В начале марта 1938 г., после нескольких лет поисков, американские геологи обнаружили в восточной части королевства гигантские залежи нефти. Такие проблемы, как выплата "нефтекеросиновых" долгов или покупка энергоресурсов, перестали быть головной болью для Ибн Сауда, оказавшегося правителем страны, в которой находится четверть мировых запасов “чёрного золота” (С. 453).

Вячеслав Белокреницкий доктор исторических наук 